\title{
Osteoprotegerin and 25-hydroxy vitamin D levels in patients with diabetic foot
}

\author{
Diyabetik ayaklı hastalarda osteoprotegerin ve 25-hidroksi D vitamini düzeyleri
}

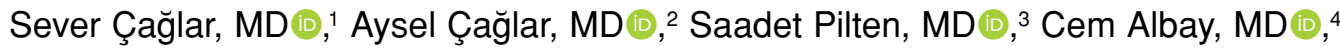 \\ Ozan Beytemur, MD (iD, ${ }^{1}$ Hakan Sarı, MD (iD ${ }^{5}$
}

'Department of Orthopedics and Traumatology, University of Health Sciences, Bağcılar Training and Research Hospital, İstanbul, Turkey ${ }^{2}$ Department of Medical Pathology, University of Health Sciences, Bağcılar Training and Research Hospital, İstanbul, Turkey

${ }^{3}$ Biochemistry Laboratory, University of Health Sciences, Bağcılar Training and Research Hospital, İstanbul, Turkey ${ }^{4}$ Department of Orthopedics and Traumatology, University of Health Sciences, Baltalimanı Training and Research Hospital, İstanbul, Turkey ${ }^{5}$ Department of Internal Medicine, University of Health Sciences, Bağcılar Training and Research Hospital, İstanbul, Turkey

\section{ABSTRACT}

Objectives: This study aims to compare the levels of osteoprotegerin (OPG) and 25-hydroxy vitamin D (25(OH)D) in patients with diabetic foot and patients with newly diagnosed type 2 diabetes mellitus (DM) and to investigate the prevalence and severity of $25(\mathrm{OH}) \mathrm{D}$ insufficiency in patients with diabetic foot.

Patients and methods: This prospective study was conducted on 105 patients including 58 patients with diabetic foot (42 males, 16 females; mean age 63.6 years; range, 31 to 90 years), who applied to our hospital between June 2014 and May 2015, and 47 newly diagnosed type 2 DM patients (27 males, 20 females; mean age 51.4 years; range, 29 to 85 years) (control group). 25(OH)D and osteoprotegerin serum levels in both groups were measured and compared.

Results: Osteoprotegerin levels in diabetic foot group were significantly higher than the control group $(\mathrm{p}<0.05)$. The $25(\mathrm{OH})$ $\mathrm{D}$ levels in diabetic foot group were significantly lower than the control group $(\mathrm{p}<0.05)$. There were positive correlations between OPG levels and C-reactive protein (CRP) and creatinine levels in patients with diabetic foot.

Conclusion: Elevated levels of OPG in patients with diabetic foot may display the severity of the clinical status due to its positive correlation with CRP and creatinine. We detected severe $25(\mathrm{OH})$ D deficiency in the majority of diabetic foot patients. Vitamin D supplementation may be required in diabetic foot patients to prevent unfavorable immunologic alterations.

Keywords: Diabetic foot; osteoprotegerin; vitamin D.

\section{$O ̈ Z$}

Amaç: $\mathrm{Bu}$ çalışmada diyabetik ayaklı hastalarda ve yeni tanı konulmuş tip 2 diabetes mellitus (DM)'lu hastalarda osteoprotegerin (OPG) ve 25-hidroksi D vitamini $(25(\mathrm{OH}) \mathrm{D})$ düzeyleri karşılaştırıldı ve diyabetik ayaklı hastalarda $25(\mathrm{OH}) \mathrm{D}$ eksikliğinin yaygınlığ 1 ve şiddeti araştırıldı.

Hastalar ve yöntemler: Bu ileriye dönük çalışma Haziran 2014 ve Mayıs 2015 tarihleri arasında hastanemize başvuran 58 diyabetik ayaklı hasta (42 erkek, 16 kadın; ort. yaş $63.6 \mathrm{y} 1$; dağılım, 31-90 yıl) ve 47 yeni tanı konulmuş tip 2 DM'li hasta (27 erkek, 20 kadın; ort. yaş 51.4 yıl; dağılım, 29-85 yıl) (kontrol grubu) olmak üzere 105 hasta üzerinde gerçekleştirildi. Her iki grupta 25(OH)D ve OPG serum düzeyleri ölçüldü ve karşılaştırıldı.

Bulgular: Diyabetik ayak grubunda OPG düzeyleri kontrol grubundan anlamlı olarak daha yüksekti $(\mathrm{p}<0.05)$. Diyabetik ayak grubunda $25(\mathrm{OH}) \mathrm{D}$ düzeyleri kontrol grubundan anlamlı olarak daha düşüktü $(\mathrm{p}<0.05)$. Diyabetik ayaklı hastalarda OPG düzeyleri ve C-reaktif protein (CRP) ve kreatinin düzeyleri arasında pozitif ilişkiler vardı.

Sonuç: Diyabetik ayaklı hastalarda yükselmiş OPG düzeyleri, OPG'nin CRP ve kreatinin ile pozitif ilişkisine bağlı olarak klinik durumun şiddetini gösterebilir. Diyabetik ayaklı hastaların çoğunluğunda ciddi 25(OH)D eksikliği tespit edildi. Diyabetik ayaklı hastalarda istenmeyen immünolojik değişiklikleri önlemek için D vitamini suplemantasyonu gerekli olabilir.

Anahtar sözcükler: Diyabetik ayak; osteoprotegerin; D vitamini. 
Osteoprotegerin (OPG) is a glycoprotein which is a member of the tumor necrosis factor (TNF) family. Osteoprotegerin was first found in the bones. ${ }^{[1]}$ It acts as a strong antiresorptive factor. Osteoprotegerins effect is demonstrated by binding or neutralizing the receptor activator nuclear factor kappa B ligand (RANKL). ${ }^{[2]}$ Recent studies have shown that OPG is present in mesenchymal tissues and in vitro production of OPG is performed by vascular smooth muscle cells. ${ }^{[3,4]}$ Osteoprotegerin and RANKL are the two important regulators of mineral metabolism in both bone and vascular tissues. Also, OPG has been shown to be present in the arterial wall by both experimental and human studies. ${ }^{[5,6]}$ Peripheral artery disease (PAD) is the underlying predisposing factor in the etiology of the majority of diabetic feet. A strong relationship between serum OPG level and severity of PAD was reported in 67 patients by Ziegler et al. ${ }^{[7]}$ Vitamin D plays a role in calcium and bone metabolism and it is known to be an important immune modulator agent. ${ }^{[8,9]}$ Receptors for activated vitamin $\mathrm{D}$ form on pancreatic beta cells and immunosuppressive cells have been described ${ }^{[10,11]}$ Evidence for the relationship between vitamin $\mathrm{D}$ deficiency and bacterial and viral infections is also available. ${ }^{[12,13]}$ Vitamin D provides the death of macrophage-mediated bacteria and stimulates phagocytosis. Vitamin D deficiency poses a possible risk for diabetic foot infections in diabetic patients. ${ }^{[14]}$ Therefore, in this study, we aimed to compare the levels of OPG and 25-hydroxy vitamin $\mathrm{D}(25(\mathrm{OH}) \mathrm{D})$ in patients with diabetic foot and patients with newly diagnosed type 2 diabetes mellitus (DM) and to investigate the prevalence and severity of 25(OH)D insufficiency in patients with diabetic foot. ${ }^{[15]}$

\section{PATIENTS AND METHODS}

This prospective study was conducted on 105 patients including 58 patients with diabetic foot (42 males, 16 females; mean age 63.6 years; range, 31 to 90 years), who applied to Bağcllar Training and Research Hospital between June 2014 and May 2015, and 47 newly diagnosed type 2 DM patients (27 males, 20 females; mean age 51.4 years; range, 29 to 85 years) (control group). The study protocol was approved by the Bağcllar Training and Research Hospital Ethics Committee (2014/247). A written informed consent was obtained from each patient. The study was conducted in accordance with the principles of the Declaration of Helsinki.

The diabetic foot group was selected from patients with PAD. Arterial Doppler ultrasonography was performed and diabetic feet with particularly neuropathic pain were not included. Diabetic foot group consisted of patients with biphasic, monophasic or non-flowable anterior dorsalis pedis and posterior tibial artery diabetic feet. Wound ulcers in patients with diabetic foot were classified according to Wagner's classification (Table I): grade $1, \mathrm{n}=6$; grade 2 , $\mathrm{n}=22$; grade $3, \mathrm{n}=19$; grade $4, \mathrm{n}=8$; and grade $5, \mathrm{n}=3$.

Serum concentration of $25(\mathrm{OH}) \mathrm{D}$ was determined by using electrochemiluminescence immunoassay utilized in fasting patients' morning blood samples. Serum concentration of OPG was determined by enzyme-linked immunosorbent assay (ELISA) (eBioscience kit, Bender Medsystems GmbH Campus Vienna Biocenter 2, Vienna, Austria) using the same blood samples. Blood samples were collected into yellow blood collection tubes, their serum was separated, and aliquots of $300 \mu \mathrm{L}$ were stored frozen at $-80^{\circ} \mathrm{C}$ until analysis. For OPG ELISA eBioscience kit, reference values for normal serum samples were $5-100 \mathrm{pg} / \mathrm{mL}$.

\section{Statistical analysis}

IBM SPSS version 22.0 software (IBM Corp. Armonk, NY, USA) was used for statistical analyses. Mean, standard deviation, median lowest, highest, frequency and ratio values were used in the descriptive statistics of the data. Distribution of the variables was measured by the Kolmogorov-Smirnov test. Independent sample t-test and Mann-Whitney U test were used in the analysis of quantitative independent data while chi-square test was used in the analysis of qualitative independent data. Spearman correlation analysis was used for correlation analysis.

\section{RESULTS}

The age of the patients with diabetic foot was significantly higher than the control group $(p>0.05)$. Gender distribution between diabetic foot patients and control group did not differ significantly $(\mathrm{p}<0.05)$ (Tables II and III). The duration of diabetes in the diabetic foot group was significantly higher than the control group $(\mathrm{p}<0.05)$ (Tables II and III).

\section{TABLE}

Wagner's classification

\begin{tabular}{ll}
\hline Grade 0 & Skin at risk \\
Grade 1 & Superficial ulcer \\
Grade 2 & Exposed tendon and deep structures \\
Grade 3 & Deep ulcers with abscess or osteomyelitis \\
Grade 4 & Partial gangrene \\
Grade 5 & More extensive gangrene \\
\hline
\end{tabular}


TABLE II

Median and minimum-maximum age, vitamin D level, duration of diabetes, osteoprotegerin and hemoglobin A1c levels in both groups. Median and minimum-maximum C-reactive protein and creatinine in study group

\begin{tabular}{|c|c|c|c|c|c|}
\hline & $\mathrm{n}$ & $\%$ & Mean $\pm S D$ & Median & Min-Max \\
\hline Age (year) & & & $58.1 \pm 12.7$ & 59.0 & $29.0-90.0$ \\
\hline \multicolumn{6}{|l|}{ Gender } \\
\hline Female & 36 & 34.3 & & & \\
\hline Male & 69 & 65.7 & & & \\
\hline Vitamin D level & & & $9.6 \pm 6.6$ & 7.7 & $1.0-33.0$ \\
\hline Duration of diabetes (year) & & & $9.8 \pm 6.6$ & 9.0 & $1.0-34.0$ \\
\hline Osteoprotegerin level (pg/mL) & & & $125.4 \pm 88.4$ & 96.0 & $34.0-541.0$ \\
\hline Hemoglobin A1c & & & $7.9 \pm 2.3$ & 7.0 & $4.6-14.9$ \\
\hline C-reactive protein & & & $54.6 \pm 62.2$ & 31.0 & $0.7-253.0$ \\
\hline Creatinine & & & $1.9 \pm 1.8$ & 1.2 & $0.5-8.0$ \\
\hline
\end{tabular}

SD: Standard deviation; Min: Minimum; Max: Maximum.

TABLE III

Mean and median age, gender, duration of diabetes, vitamin D level, osteoprotegerin and hemoglobin A1c levels in study and control groups. Mean and median C-reactive protein and creatinine in study group

\begin{tabular}{|c|c|c|c|c|c|c|c|c|c|}
\hline & \multicolumn{4}{|c|}{ Study group } & \multicolumn{4}{|c|}{ Control group } & \multirow[b]{2}{*}{$p$} \\
\hline & $\mathrm{n}$ & $\%$ & Mean $\pm S D$ & Median & $\mathrm{n}$ & $\%$ & Mean \pm SD & Median & \\
\hline Age (year) & & & $63.6 \pm 10.7$ & 64.5 & & & $51.4 \pm 11.7$ & 51.0 & $0.000^{*}$ \\
\hline Gender & & & & & & & & & $0.108 \dagger$ \\
\hline Female & 16 & 27.6 & & & 20 & 42.6 & & & \\
\hline Male & 42 & 72.4 & & & 27 & 57.4 & & & \\
\hline Duration of diabetes (year) & & & $14.3 \pm 5.5$ & 13.5 & & & $4.2 \pm 1.7$ & 4.0 & $0.000 \ddagger$ \\
\hline Vitamin D level & & & $7.9 \pm 6.3$ & 6.3 & & & $11.6 \pm 6.5$ & 9.8 & $0.000 \ddagger$ \\
\hline Osteoprotegerin level $(\mathrm{pg} / \mathrm{mL})$ & & & $154.0 \pm 100.3$ & 115.0 & & & $90.0 \pm 53.7$ & 80.0 & $0.000 \ddagger$ \\
\hline Hemoglobin A1c & & & $7.8 \pm 2.1$ & 7.4 & & & $8.0 \pm 2.5$ & 6.7 & $0.759 \ddagger$ \\
\hline C-reactive protein & & & $54.6 \pm 62.2$ & 31.0 & & & & - & \\
\hline Creatinine & & & $1.9 \pm 1.8$ & 1.2 & & & & - & \\
\hline
\end{tabular}

SD: Standard deviation; * $t$ test; $†$ Chi-square test; $\ddagger$ Mann-Whitney $U$ test.

The $25(\mathrm{OH}) \mathrm{D}$ value in the diabetic foot group was significantly lower than the control group $(p<0.05)$ (Tables II and III) (Figure 1). Osteoprotegerin levels in diabetic foot group were significantly higher than the control group $(\mathrm{p}<0.05)$ (Tables II and III) (Figure 2). The hemoglobin A1c (HbA1c) value did not differ significantly between the diabetic foot and control groups $(\mathrm{p}>0.05)$ (Table II). There was significant positive correlation between OPG level and CRP value $(\mathrm{r}=0.379, \mathrm{p}<0.05)$ (Table IV) (Figure 3). There was significant positive correlation between OPG level and creatinine value $(\mathrm{r}=0.562, \mathrm{p}<0.05)$ (Table IV) (Figure 4).

\section{DISCUSSION}

Osteoprotegerin levels are positively associated with age, ${ }^{[16]}$ diabetes, ${ }^{[17]}$ renal insufficiency, ${ }^{[18]}$ CRP, fibrinogen interleukin 6 (IL-6) and glycemic status. ${ }^{[19-21]}$ It is also associated with cardiac mortality. ${ }^{[22,23]}$ Recent studies have reported that a high OPG level is an independent risk factor

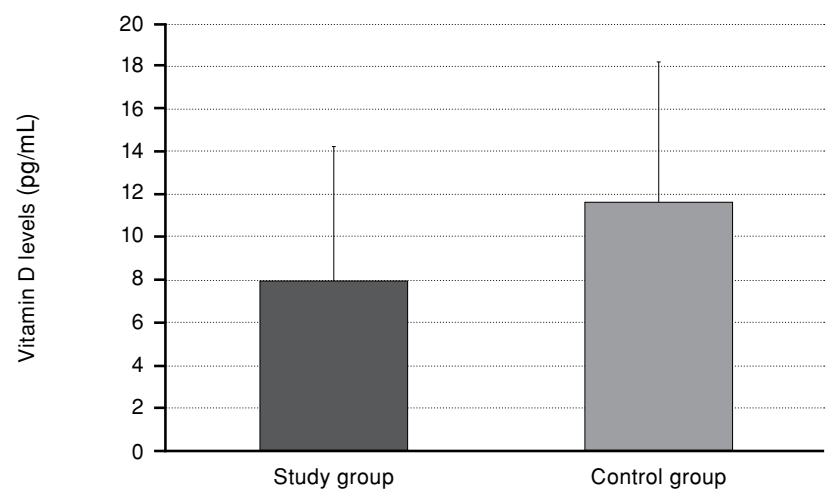

Figure 1. Vitamin D levels of study and control groups. 


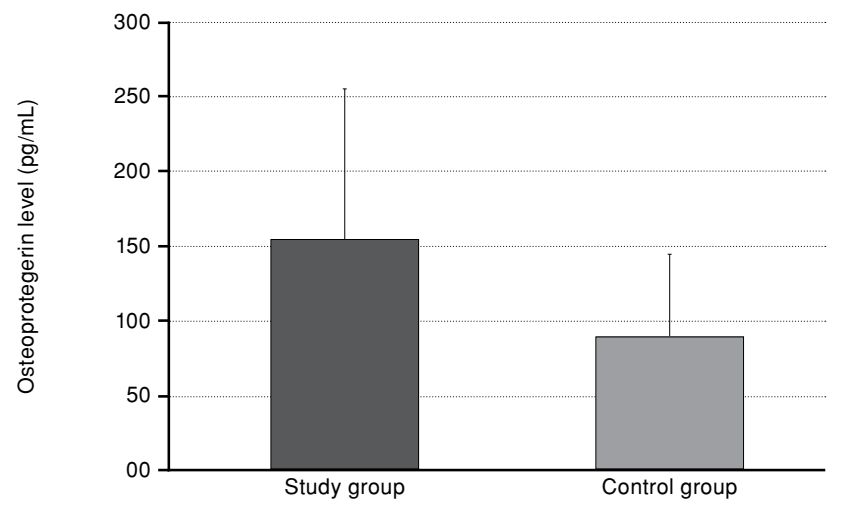

Figure 2. Osteoprotegerin levels of study and control groups.

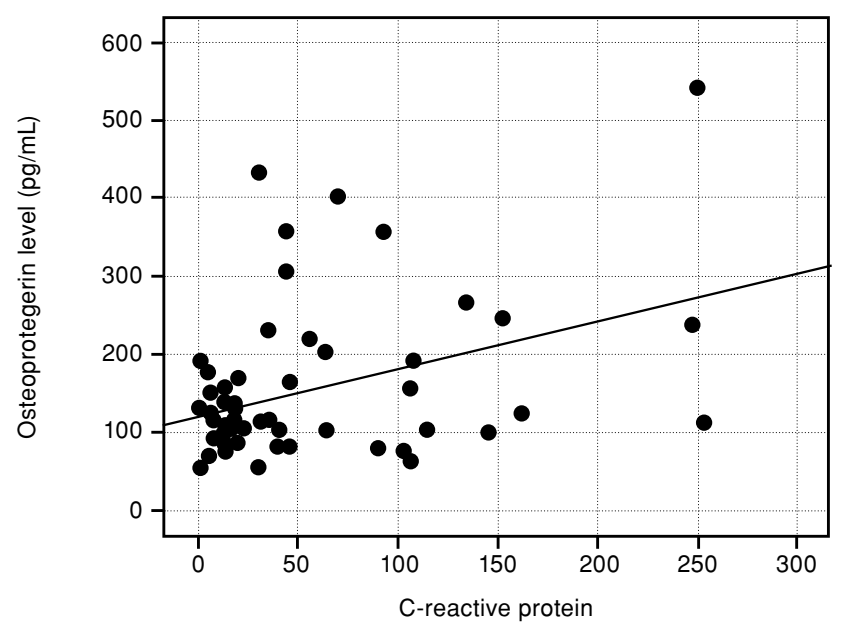

Figure 3. Correlation between osteoprotegerin level and C-reactive protein.

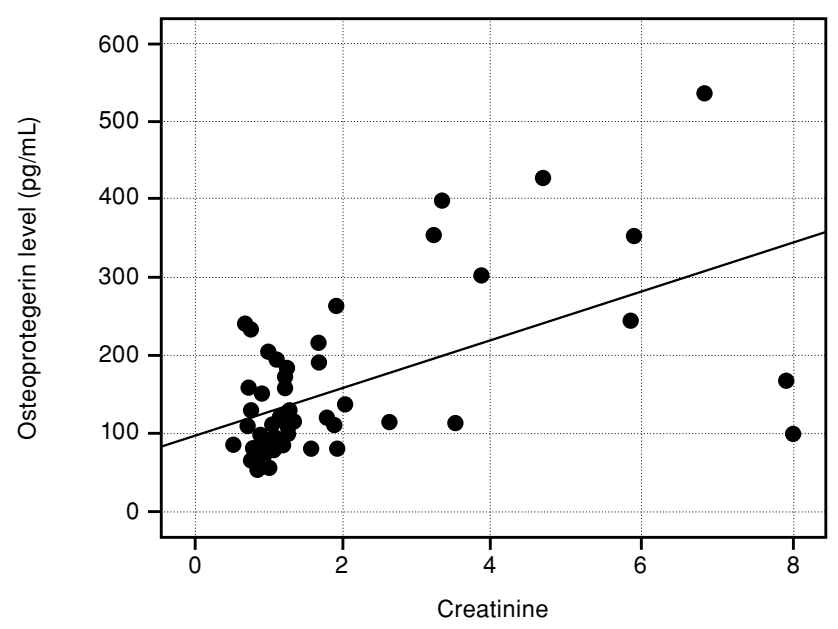

Figure 4. Correlation between osteoprotegerin and creatinine levels. for progressive arteriosclerosis. ${ }^{[17]}$ OPG is a new marker for PAD. ${ }^{[24]}$ It is more cost-effective and less invasive than angiography, which has renal side effects. Rasmussen et al. ${ }^{[21]}$ demonstrated that plasma OPG was higher in nephropathic type 1 diabetic patients than type 1 patients without nephropathy. Furthermore, a study of 46 predialysis patients with kidney failure demonstrated that OPG increased with decreased kidney function, as determined by creatinine clearance. The mentioned study showed the same association between glomerular filtration rate and OPG levels among patients with diabetic nephropathy. They also found significant correlations between plasma OPG levels and cardiovascular status. This correlation seemed relatively strong and independent of kidney function and was observed both in normoalbuminuric and nephropathic patients. Kim et al. ${ }^{[20]}$ detected that serum OPG levels significantly correlate with fasting blood glucose, IL-6 and CRP levels.

In our study, OPG levels in patients with diabetic foot were significantly higher than the diabetic control group (Figure 2, Table II). Moreover, there was a positive correlation with CRP and creatinine values (Figures 3 and 4, Table IV). Osteoprotegerin levels were approximately $4-5$ times higher in patients with diabetic foot in which CRP and creatinine levels were increased together. Creatinine levels probably increase when severity of necrosis and infections in diabetic feet increase, and OPG levels probably increase very seriously, as we have observed in our study. Very increased OPG may be indicative of severe endothelial damage in veins and increased cardiac mortality. ${ }^{[22,23]}$ Increased OPG levels in patients with diabetic foot may demonstrate existing vascular damage. Osteoprotegerin may also display the severity of the clinical status in these patients due to its positive correlation with CRP and creatinine (Table IV, Figures 3 and 4).

In this study, we also investigated the $25(\mathrm{OH}) \mathrm{D}$ levels in diabetic feet. In the guideline for diagnosis and treatment of metabolic bone diseases published

\section{TABLE IV}

Positive association of osteoprotegerin level with creatinine and C-reactive protein

\begin{tabular}{lcc}
\hline & Creatinine & CRP \\
\hline Osteoprotegerin level $(\mathrm{pg} / \mathrm{mL})$ & & \\
$r$ & 0.562 & 0.379 \\
$\mathrm{p}$ & 0.000 & 0.003 \\
\hline
\end{tabular}

CRP: C-reactive protein; Spearman correlation. 


\section{TABLE V}

Patients' Vitamin D status according to serum 25(OH)D level

\begin{tabular}{lc}
\hline Vitamin D statue & $25(\mathrm{OH}) \mathrm{D}$ level $(\mathrm{ng} / \mathrm{mL})$ \\
\hline Significant vitamin D deficiency & $<10$ \\
Vitamin D deficiency & $11-20$ \\
Insufficiency & $21-30$ \\
Normal & $31-100$ \\
\hline
\end{tabular}

in 2012 by the Turkish Society of Endocrinology and Metabolism, 25(OH)D was evaluated in four categories according to serum concentration: significant vitamin D deficiency if serum $25(\mathrm{OH}) \mathrm{D}$ is $<10 \mathrm{ng} / \mathrm{mL}$, vitamin $D$ deficiency if $11-20 \mathrm{ng} / \mathrm{mL}$, vitamin $\mathrm{D}$ insufficiency if $21-30 \mathrm{ng} / \mathrm{mL}$, and normal if $>30 \mathrm{ng} / \mathrm{mL}$ (Table V).

We detected 25(OH)D deficiency or serious deficiency in the majority of our diabetic foot patients. The control group also had widespread $25(\mathrm{OH}) \mathrm{D}$ deficiency. However, when compared statistically, $25(\mathrm{OH}) \mathrm{D}$ levels in diabetic foot patients were significantly lower (Figure 1). We found that the average $25(\mathrm{OH}) \mathrm{D}$ level in patients with diabetic foot was $7.9 \mathrm{ng} / \mathrm{mL}$ (Tables II and III). Tiwari et al. ${ }^{[25]}$ have suggested that vitamin $\mathrm{D}$ deficiency escalated inflammatory cytokine release (IL-1 $\beta$, IL- 6 , TNF- $\alpha$ ) in patients with diabetic foot infection, particularly when its serum concentration was very low. Therefore, they suggest a $25(\mathrm{OH}) \mathrm{D}$ value $<10 \mathrm{ng} / \mathrm{mL}(25 \mathrm{nmol} / \mathrm{L})$ as the 'cut-off' for unfavorable immunological alterations in patients with diabetes mellitus. ${ }^{[25]}$ It is shown that polymorphonuclear leukocytes and IL-1 $\beta$ regulation deteriorate in patients with diabetic foot infection. ${ }^{[26]}$

Vitamin $\mathrm{D}$ suppresses $\mathrm{T}$ cell proliferation and decreases the production of the $\mathrm{T}$ helper type 1 cytokines while promoting the production of $\mathrm{T}$ helper type 2 cytokines. ${ }^{[27]} \mathrm{T}$ helper type 2 cells primarily play a role in response to extracellular pathogens. ${ }^{[14]}$ Tiwari et al. ${ }^{[14]}$ emphasized that in addition to hyperglycemia; vitamin D deficiency may lead to increased risk of infection in diabetic foot patients, as it causes a decrease in immunoreactive cells that respond to infection.

We observed clinically that diabetic foot infections healed after abscess drainage, glycemic control, antibiotic therapy and vitamin D supplementation. Diabetic foot develops in the later stages of diabetes in general. In our study, we also found that the average age and the duration of disease in diabetic foot patients were higher than the control group.
In conclusion, we demonstrated that OPG levels were increased in patients with diabetic foot. Elevated OPG levels in diabetic foot patients may indicate the severity of the clinical status due to its positive correlation with CRP, creatinine, vascular endothelial damage and glycemic status. However, future studies are required to provide additional information in this field. Vitamin D deficiency is commonly observed in diabetic foot patients. Thus, diabetic foot patients with 25(OH)D levels lower than $10 \mathrm{ng} / \mathrm{mL}$ should be supplemented with vitamin $\mathrm{D}$ to prevent unfavorable immunological alterations.

\section{Declaration of conflicting interests}

The authors declared no conflicts of interest with respect to the authorship and/or publication of this article.

\section{Funding}

The authors received no financial support for the research and/or authorship of this article.

\section{REFERENCES}

1. Rasmussen LM, Ledet T. Osteoprotegerin and diabetic macroangiopathy. Horm Metab Res 2005;37:90-4.

2. Simonet WS, Lacey DL, Dunstan CR, Kelley M, Chang MS, Lüthy $R$, et al. Osteoprotegerin: a novel secreted protein involved in the regulation of bone density. Cell 1997;89:309-19.

3. Fu M, Zhang J, Lin Yg Yg, Zhu X, Willson TM, Chen YE. Activation of peroxisome proliferator-activated receptor gamma inhibits osteoprotegerin gene expression in human aortic smooth muscle cells. Biochem Biophys Res Commun 2002;294:597-601.

4. Zhang J, Fu M, Myles D, Zhu X, Du J, Cao X, et al. PDGF induces osteoprotegerin expression in vascular smooth muscle cells by multiple signal pathways. FEBS Lett 2002;521:180-4.

5. Ovchinnikova O, Gylfe A, Bailey L, Nordström A, Rudling M, Jung C, et al. Osteoprotegerin promotes fibrous cap formation in atherosclerotic lesions of ApoEdeficient mice--brief report. Arterioscler Thromb Vasc Biol 2009;29:1478-80.

6. Morony S, Tintut Y, Zhang Z, Cattley RC, Van G, Dwyer D, et al. Osteoprotegerin inhibits vascular calcification without affecting atherosclerosis in $\operatorname{ldl}(-/ /-)$ mice. Circulation 2008;117:411-20.

7. Ziegler S, Kudlacek S, Luger A, Minar E. Osteoprotegerin plasma concentrations correlate with severity of peripheral artery disease. Atherosclerosis 2005;182:175-80.

8. Baeke F, Etten EV, Overbergh L, Mathieu C. Vitamin D3 and the immune system: maintaining the balance in health and disease. Nutr Res Rev 2007;20:106-18.

9. Cantorna MT, Zhu Y, Froicu M, Wittke A. Vitamin D status, 1,25-dihydroxyvitamin D3, and the immune system. Am J Clin Nutr 2004;80:1717-20.

10. Chiu KC, Chu A, Go VL, Saad MF. Hypovitaminosis $\mathrm{D}$ is associated with insulin resistance and beta cell dysfunction. Am J Clin Nutr 2004;79:820-5. 
11. Veldman CM, Cantorna MT, DeLuca HF. Expression of 1,25-dihydroxyvitamin $\mathrm{D}(3)$ receptor in the immune system. Arch Biochem Biophys 2000;374:334-8.

12. Kawarau A, Takeda E, Tanida N, Nakagawa K, Yamamoto $\mathrm{H}$. Inhibitory effect of long term 1-alpha-hydroxyvitamin $\mathrm{D}_{3}$ administration on Helicobacter pylori infection. J Clin Biochem Nutr 2006;38:103-6.

13. Sabetta JR, DePetrillo P, Cipriani RJ, Smardin J, Burns LA, Landry ML. Serum 25-hydroxyvitamin d and the incidence of acute viral respiratory tract infections in healthy adults. PLoS One 2010;5:11088.

14. Tiwari S, Pratyush DD, Gupta B. Prevalence and severity of vitamin D deficiency in patients with diabetic foot infection. Br J Nutr 2013;109:99-102.

15. Atik OŞ. Are all case reports worth publishing? Eklem Hastalik Cerrahisi 2016;27:61.

16. Szulc P, Hofbauer LC, Heufelder AE, Roth S, Delmas PD. Osteoprotegerin serum levels in men: correlation with age, estrogen, and testosterone status. J Clin Endocrinol Metab 2001;86:3162-5.

17. Knudsen ST, Jeppesen P, Poulsen PL, Andersen NH, Bek T, Schmitz $\mathrm{O}$, et al. Plasma concentrations of osteoprotegerin during normo- and hyperglycaemic clamping. Scand J Clin Lab Invest 2007;67:135-42.

18. Kazama JJ, Shigematsu T, Yano K, Tsuda E, Miura M, Iwasaki $\mathrm{Y}$, et al. Increased circulating levels of osteoclastogenesis inhibitory factor (osteoprotegerin) in patients with chronic renal failure. Am J Kidney Dis 2002;39:525-32.

19. Kiechl S, Schett G, Wenning G, Redlich K, Oberhollenzer $\mathrm{M}$, Mayr A, et al. Osteoprotegerin is a risk factor for progressive atherosclerosis and cardiovascular disease. Circulation 2004;109:2175-80.
20. Kim SM, Lee J, Ryu OH, Lee KW, Kim HY, Seo JA, et al. Serum osteoprotegerin levels are associated with inflammation and pulse wave velocity. Clin Endocrinol (Oxf) 2005;63:594-8.

21. Rasmussen LM, Tarnow L, Hansen TK, Parving $\mathrm{HH}$, Flyvbjerg A. Plasma osteoprotegerin levels are associated with glycaemic status, systolic blood pressure, kidney function and cardiovascular morbidity in type 1 diabetic patients. Eur J Endocrinol 2006;154:75-81.

22. Jono S, Ikari Y, Shioi A, Mori K, Miki T, Hara K, et al. Serum osteoprotegerin levels are associated with the presence and severity of coronary artery disease. Circulation 2002;106:1192-4.

23. Schoppet M, Sattler AM, Schaefer JR, Herzum M, Maisch $B$, Hofbauer LC. Increased osteoprotegerin serum levels in men with coronary artery disease. J Clin Endocrinol Metab 2003;88:1024-8.

24. Shin JY, Shin YG, Chung CH. Elevated serum osteoprotegerin levels are associated with vascular endothelial dysfunction in type 2 diabetes. Diabetes Care 2006;29:1664-6.

25. Tiwari S, Pratyush DD, Gupta SK, Singh SK. Vitamin $\mathrm{D}$ deficiency is associated with inflammatory cytokine concentrations in patients with diabetic foot infection. Br J Nutr 2014;112:1938-43.

26. Oncul O, Yildiz S, Gurer US, Yeniiz E, Qyrdedi T, Top C, et al. Effect of the function of polymorphonuclear leukocytes and interleukin-1 beta on wound healing in patients with diabetic foot infections. J Infect 2007;54:250-6.

27. van Etten E, Mathieu C. Immunoregulation by 1,25-dihydroxyvitamin D3: basic concepts. J Steroid Biochem Mol Biol 2005;97:93-101. 